\title{
SUITABILITY OF DRAINAGE WATER FOR IRRIGATION AND ITS IMPACT ON WHEAT AND CLOVER CROPS AT NORTHERN DELTA, EGYPT \\ Taha, A. A. ${ }^{1}$; M. E. El-Shehawy ${ }^{2}$; A. A. Mosa ${ }^{1}$ and M. N. EL-Komy ${ }^{2}$ \\ ${ }^{1}$ Soils Dept., Fac. of Agric., Mansoura Univ., Egypt. \\ ${ }^{2}$ Soils, Water and Environment Res. Inst., A.R.C., Egypt.
}

\begin{abstract}
As a result of the shortage in fresh water supplies for irrigation in North Delta region, drainage water are used for irrigation. Drains in North Delta region are used for receiving sewage water, agricultural drainage water and industrial drainage water, therefore, it becomes a dangerous source of pollution as it contains different pollutants. This study aims to evaluate the suitability of drainage water for irrigation purpose in Kafr EL-Shiekh Governorate at North Delta and it's impact of cultivated crops (Wheat and Berseem).Drainage samples were seasonally collected from three main drains (El Gharbia main drain, drain No.11 and drain No.10) from fixed sites along the distance of each drain during year of 2010. Drainage samples were chemically analyzed to determine salinity\& sodicity hazard, Boron, heavy metals (i.e. $\mathrm{Cu}^{2+}, \mathrm{Mn}^{2+}, \mathrm{Pb}^{2+}$ and $\mathrm{Cd}^{2+}$ ) and nitrate concentrations. On the other hand, plant samples were collected from the same sites and subjected to the chemical analysis to evaluate the effect of drainage water for irrigation on their chemical analysis.

The main obtained results could be summarized as follows:

- Electrical conductivity (EC) and sodium absorption ratio (SAR) values increased slightly at northward direction and the quality of these drainage water resources was acceptable as the degree of restriction in use which ranged from " none" to" Slight to moderate" according to (FAO,1985). There for, it could be used for irrigation most crops.

- $\quad \mathrm{pH}$ values were in the normal range (6.5-8.4) in the examined drainage water resources.

- Boron (B) values recorded low concentration in most drains ( $<1.3 \mathrm{mg} / \mathrm{L})$, which less than the critical limit.

- Heavy metal ions concentration $\left(\mathrm{Mn}^{2+}, \mathrm{Cu}^{2+}, \mathrm{Pb}^{2+}\right.$ and $\left.\mathrm{Cd}^{2+}\right)$ were less than the permissible levels given by National Academy (1972).

- Nitrate $-\mathrm{N}$ concentrations increased in EL-Gharbia main drain over than permissible limit in some locations during September and December; however, it was less than the permissible limit in the other drains.

- Heavy metals concentration ( $\mathrm{Mn}, \mathrm{Cu}, \mathrm{Pb}$ and $\mathrm{Cd}$ ) and $\mathrm{B}$ in wheat ( straw and grains) were under the permissible limits in most locations. However, $\mathrm{Cu}$ concentration exceeds the critical levels in all locations. Regarding clover plants, the corresponding values of heavy metal were less than the permissible limits in all locations except $\mathrm{Pb}$ concentration in some locations
\end{abstract}

\section{INTRODUCTION}

The Egyptian water budget is quantified as 55.5 billion $\mathrm{m}^{3} / \mathrm{yr}$ and the River Nile is the main source of the Egyptian Water budget. In addition, there are other additional rainfalls in the North-Western coast and Sinai, in addition to groundwater aquifers in the western desert. On the other hand, the average demand for water is about 75 billion $\mathrm{m}^{3} / \mathrm{yr}$. The gap between 
Taha, A. A. et al.

available water resources and needs is about 20 billion $\mathrm{m}^{3} / \mathrm{yr}$. This gap could be overcome by reusing non-conventional water resources (via agricultural drainage water, treated wastewater and groundwater). Therefore, farmers usually use drainage water in case of shortage of fresh water, especially at the terminals of irrigation canals. At present, there are 20 reuse pumping stations for mixing drainage water with canal water. Farmers at the tail end of irrigation canals use the drainage water officially (reusing after mixing) and unofficially (reusing drainage water directly for irrigation).Overtime, the low quality water had led to the following adverse effects:

- Degradation of soil properties and consequently reduction of agriculture production.

- Degradation of crop quality and its suitability for human consumption.

- Degradation of groundwater quality.

- Threats for aquatic plant eco-system (Eutrophication and Biodiversity and fisheries).

In addition to, the lack of farmers awareness about the use of low quality water for irrigation has led to hygiene problems for farmers and farm animals as result of pollutants and parasites.

Khalifa (1990) evaluated drainage water of EL-Gharbia main drain for irrigation purposes in Kafr EL-Shiekh and showed that the drainage water of EL-Gharbia main lies in class $\left(\mathrm{C}_{3}-\mathrm{S} 1\right)$ according to the diagram of U.S.S.L (1954). EL-Sanakary (1994) in his study on some drains in the North Nile Delta region (drain No.1, EL-Gharbia main drain and drain No.11) found that , $\mathrm{Fe}^{2+}, \mathrm{Cu}^{2+}$ and $\mathrm{pb}^{2+}$ concentrations in the drainage water were generally found to be under the maximum recommended limits; however, $\mathrm{Mn}^{2+}, \mathrm{Zn}^{2+}$ concentrations were found to be slightly above the maximum recommended limits. Abo-waly et al. (1998) in his study on drains in kafr EL-Sheik Governorate stated that the quality of studied drainage water located in C3 S1 and C4 S3 classes and could be re-use in irrigation purpose under special management . They, also added that concentration of most heavy metals in different investigated drains were lower than the maximum permissible limits in irrigation water. El-Shahawy and Ragab (2005) determined some heavy metals concentration in El-Gharbia main drain. The results illustrated that the concentration of $\mathrm{Pb}, \mathrm{Cd}, \mathrm{Ni}$ and $\mathrm{B}$ were less than the permissible limits for irrigation.

When wastewater will be used continuously as the sole source of irrigation water for field crops in arid region, excessive amounts of nutrients and toxic chemical substances could simultaneously be applied to the soilplant system. This would cause unfavorable effects on productivity and quality parameters of the crops and the soil (Rusan et al., 2007). Zean et al. (2002a) reported that the content of heavy metal in wheat straw were higher with using low water quality for irrigation as compared with the mixed or fresh water resources. Abd El-Hady(2007) demonstrated that there are much higher concentrations of $\mathrm{Mn}, \mathrm{Cu}, \mathrm{Ni}, \mathrm{pb}$ and $\mathrm{Cd}$ in plants, which irrigated with drainage water as water compared to plants irrigated with fresh water, from canals. 
The aim of this work was to evaluate the quality of drainage water as a secondary source for irrigation in Kafer EL-Sheikh Governorate and the impact of irrigation with drainage water on wheat and clover crops.

\section{MATERIALS AND METHODS}

Location of the experiment.

Al-Gharbia main drain: its length about $56.5 \mathrm{~km}$, it serve region about 240500 Fadden and receive drainage water, wastewater and industrial effluents

Drain No.10: its length about $21.550 \mathrm{~km}$, it serve region about 17000 Fadden and receive drainage water from adjacent fields and wastewater from adjacent village.

Drain No.11 : its length about $18.860 \mathrm{~km}$, it serve region about 57000 Fadden and receives drainage water from adjacent fields and adjacent villages.

Table (1): Locations samples under the present study

\begin{tabular}{|c|c|}
\hline Drain & Site \\
\hline $\begin{array}{l}\text { EL-Ghrbia } \\
\text { drain }\end{array}$ & $\begin{array}{l}\text { main Dokhmas, Elkarakate, Elhamoul and ABOsekine (blended } \\
\text { fresh and drainage waterr) }\end{array}$ \\
\hline Drain No.10 & Kafr El-Sudan,El-Tasafy andEl-Shenawy \\
\hline Drain No.11 & Fewa,El-kairya,Abo donia andEL-Hox \\
\hline
\end{tabular}

Water samples were seasonally collected during the year of 2010 and subjected to the following analyses; $\mathrm{Ec}, \mathrm{pH}$, soluble cations \& anions, boron, heavy metals ions $\left(\mathrm{Mn}^{2+}, \mathrm{Cu}^{2+}, \mathrm{pb}^{2+}\right.$ and $\left.\mathrm{Cd}^{2+}\right)$ and nitrate concentrations.

Plant samples were collected from soils irrigated by drainage water and subjected to chemical analysis.

Table(2): Guide lines for interpretations of water quality for irrigation

\begin{tabular}{|c|c|c|c|c|}
\hline \multirow{2}{*}{$\begin{array}{c}\text { Potential irrigation } \\
\text { problem }\end{array}$} & \multirow{2}{*}{$\mathbf{d S / m}$} & \multicolumn{3}{|c|}{ Degree restriction on use } \\
\cline { 3 - 5 } & & None & $\begin{array}{c}\text { Slight to } \\
\text { moderate }\end{array}$ & Servere \\
\hline Salinity (EC) & & $<0.7$ & $0.7-3$ & $>3$ \\
\hline $\mathrm{SAR}=0-3$, and ECw & $"$ & $>0.7$ & $0.7-0.2$ & $<0.2$ \\
\hline$=3-6, \quad "$ & $"$ & $>1.2$ & $1.2-0.3$ & $<0.3$ \\
\hline$=6-12, "$ & $"$ & $>1.9$ & $1.9-0.5$ & $<0.5$ \\
\hline$=12-20, "$ " & $"$ & $>2.9$ & $2.9-1.3$ & $<1.3$ \\
\hline$=20-40, "$ & $"$ & $>5.0$ & $5.0-2.9$ & $<2.9$ \\
\hline Boron & $\mathrm{mg} / \mathrm{l}$ & $<0.7$ & $0.7-3$ & $>3$ \\
\hline Nitrate - NO3 & $\mathrm{Mg} / \mathrm{l}$ & $<5$ & $5-30$ & $>30$ \\
\hline
\end{tabular}

\section{1-Water analysis and plant analysis}

The standard method of water and plant analysis was used to identify water quality and its impact on wheat and clover as follows: 
Taha, A. A. et al.

- Ec and pH of water were determined according to Klute (1986). Also, SAR was calculated according to Richard's equation (1954)

- Concentrations of heavy metals ions in water $\left(\mathrm{Cu}^{+2}, \mathrm{Mn}^{+2}, \mathrm{pb}^{+2}\right.$ and $\left.\mathrm{Cd}^{+2}\right)$ were determined using atomic absorption spectrophotometry as described in standard methods - 302 A (APHA, 1985)

- $\mathrm{NO}_{3}-\mathrm{N}$ concentration in water was determined colorimetrically using spectrophotometer (Jackson, 1973).

- Wheat (Straw\& grains) and clover samples were dried ground and digested using a concentrated mixture of $\mathrm{H}_{2} \mathrm{SO}_{4}$ and $\mathrm{HCLO}_{4}$ at (1: 1) ratio as described by Chapman and Pratt (1961). Heavy metals concentration (Cu, $\mathrm{Mn}, \mathrm{pb}$ and $\mathrm{Cd}$ ) were determined using atomic absorption spectrophotometry according to (Page et al., 1982).

- Boron in water and digested plant samples were determined colorimetrically using spectrophotometer with Azomethine- $\mathrm{H}$ method according to Bingham (1982)

\section{RESULTS AND DISCUSSION}

\section{Seasonal variations of water chemical properties of EL-Gharbia main drain, Drain No.10 and Drain No.11:-}

Data in Table (2) shows that the EC values were increased gradually from the south to the north (in the direction of Burulus Lake) and SAR values were increased towards the north direction. The $\mathrm{pH}$ values of drainage water ranged from 7.77 to $8.24,7.7$ to 8.30 and 7.36 to 8.23 in EL-Gharbia main drain, Drain No.10 and Drain No.11, respectively.

Concentrations of, Boron, Manganese, Copper, Lead and Cadmium recorded low concentration in most locations. No clear trend was observed in the concentrations of metals related to sampling sites or time of sampling .This may due to the point source of pollution representing in wastewater discharged from different villages located near to the studied drains. According to the National Academy (1972) these concentrations are less than the recommended levels $(0.2,0.2,0.01,5.0)$ for $\mathrm{Mn}, \mathrm{Cu}, \mathrm{pb}$ and $\mathrm{Cd}$, respectively.

Evaluation of EL-Gharbia main drain ,Drain No 10 and Drain No 11 water for irrigation purpose:-

1-The salinity problem:-

The suitability of drainage water for irrigation purpose was determined by salinity and toxicity problems. Generally, in most sometimes EC values were higher in winter than in summer. EC values were slightly increased from South to North. The increase of EC value in winter than in summer may be due to little supply of drainage water to the main drains during this period. Also, lower amounts of water discharged to the drains.

The salinity problem caused by salts in all drains is evaluated by Guidelines given by FAO (1985). As shown in Table (3) in most tested seasons and at most locations the drainage water belong to one group include water having EC values up to $3.0 \mathrm{dSm}^{-1}$ and are considered to cause increasing salinity problem (FAO 1985). Therefore this water could be used 
for irrigation with restricted management practise. The usage of these water resources for irrigation required adequate drainage system and special management for salinity control and selection of plants with good salt tolerance.

2- SAR problem:-

Data in Table (3) showed that drainage water samples of EL-Gharbia main drain, drain No. 10 and Drain No. 11 could be classified into one group. This group includes drainage water having SAR values less than 10 and it could be used for irrigation most soils without any restriction according to FAO (1985).

Data in Table (3) revealed that the drainage water at having low values of $S A R$ and $E C_{d w}$ is suitable for irrigation of studied crops.

3- Boron toxicity problem:-

Boron concentrations in drainage water varied between 0.44 to $0.94,0.40$ to 1.16 and 0.40 to $1.27 \mathrm{mg} / \mathrm{L}$ in EL-Gharbia main drain, Drain No.10 and Drain No.11 (Fig.1), respectively. According to Gupta (1979) this water belongs to class1 ( $\mathrm{B} 1$-normal water, $\mathrm{B}<3 \mathrm{ppm}$ ). This water can be used for most of tolerant and semi-tolerant crops in most soils types without any injuries effects on the grain yield. According to FAO (1985), this water can be used with slight to moderate restriction.
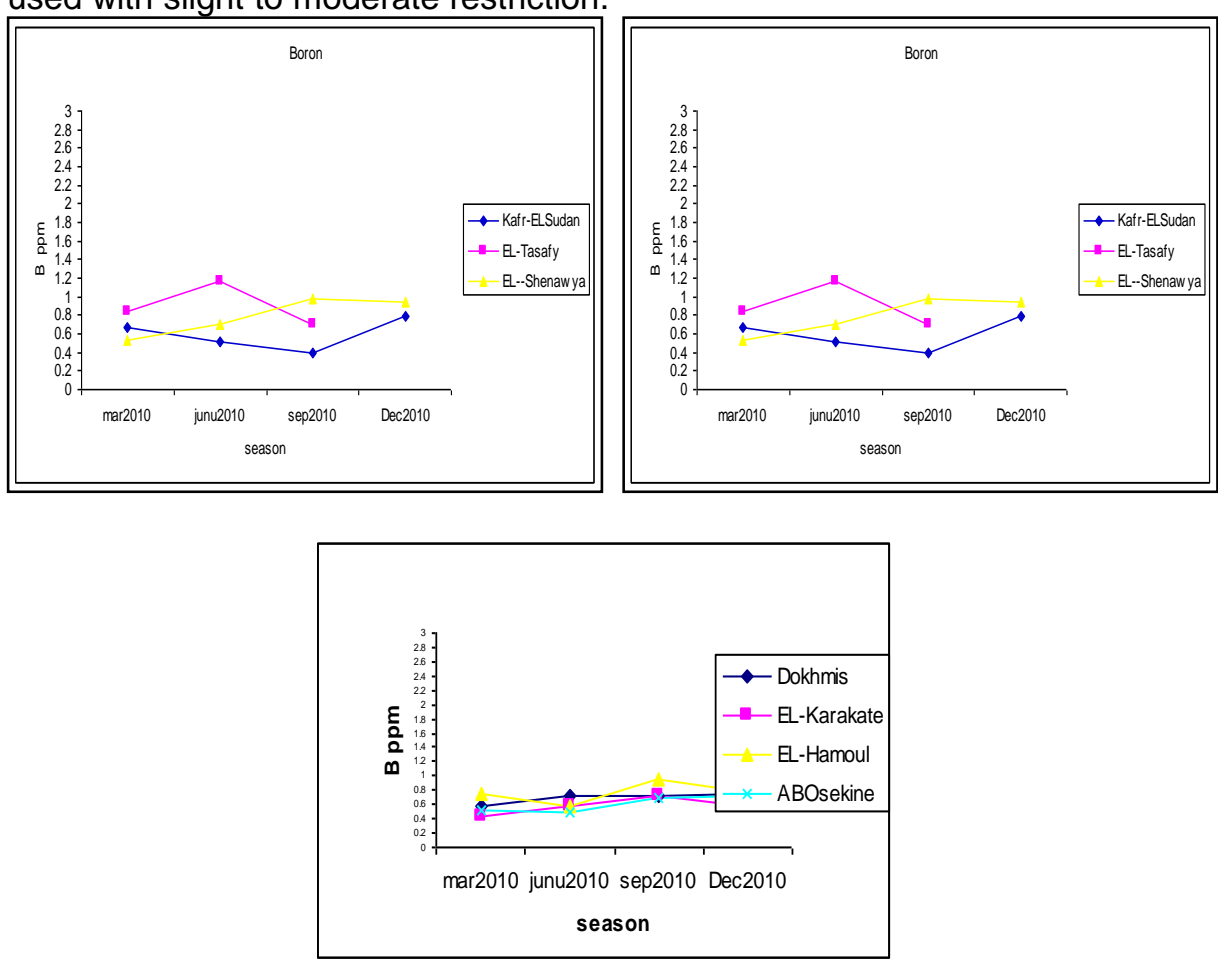

Fig. (1) The concentration of Boron in tested drains 
Taha, A. A. et al.

T3 
4- Heavy metal toxicity problem

Heavy metals concentration ( $\mathrm{Mn}, \mathrm{Cu}, \mathrm{pb}$ and $\mathrm{Cd}$ ) in the studied drains are illustrated in Figs. (2, 3 and 4). The concentrations of these metals were found to be less than the critical levels in studied seasons and at all locations according to National Academy (1972).
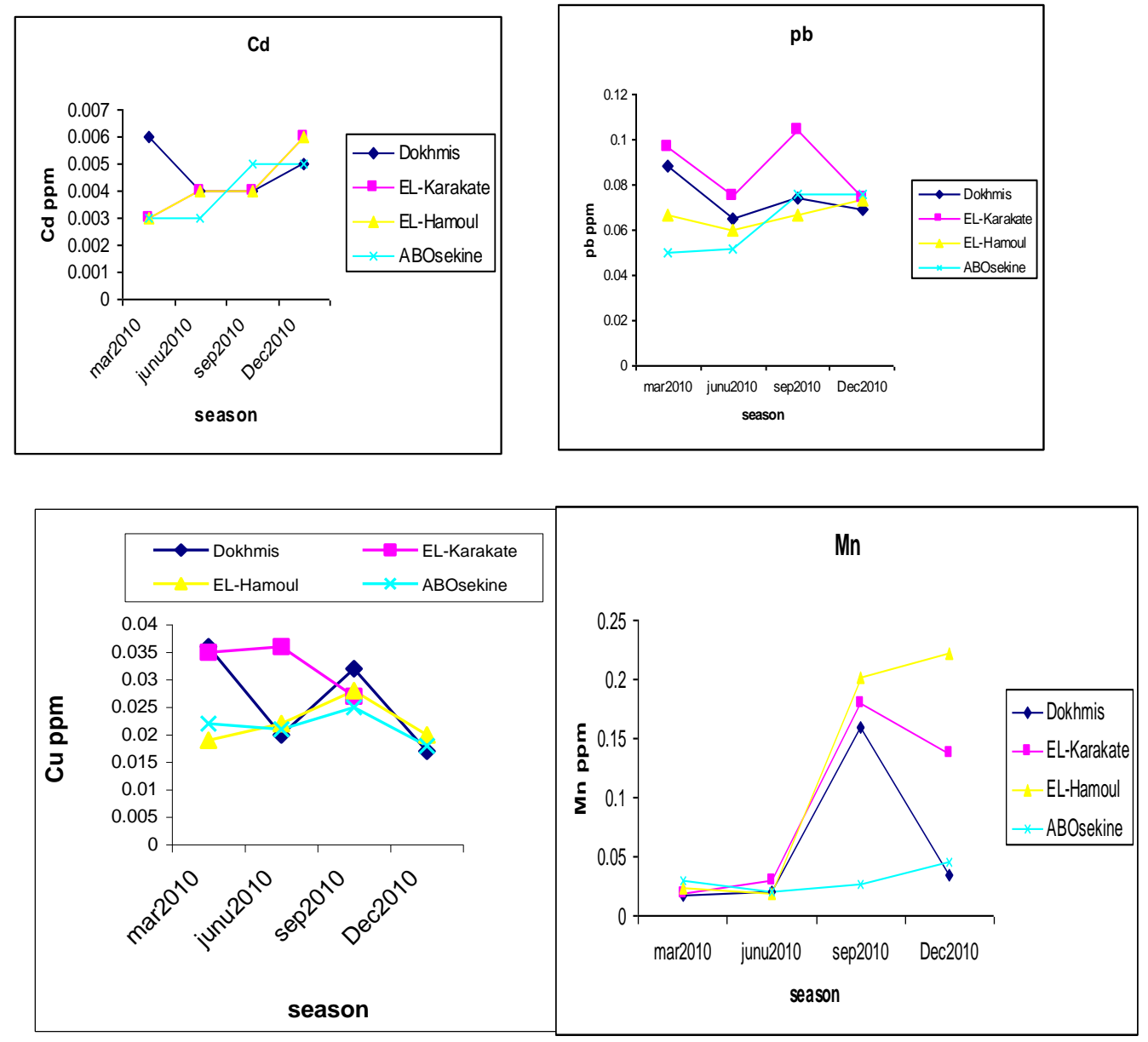

Fig.(2)The concentration of heavy metals in EL-Gharbia main drain 
Taha, A. A. et al.
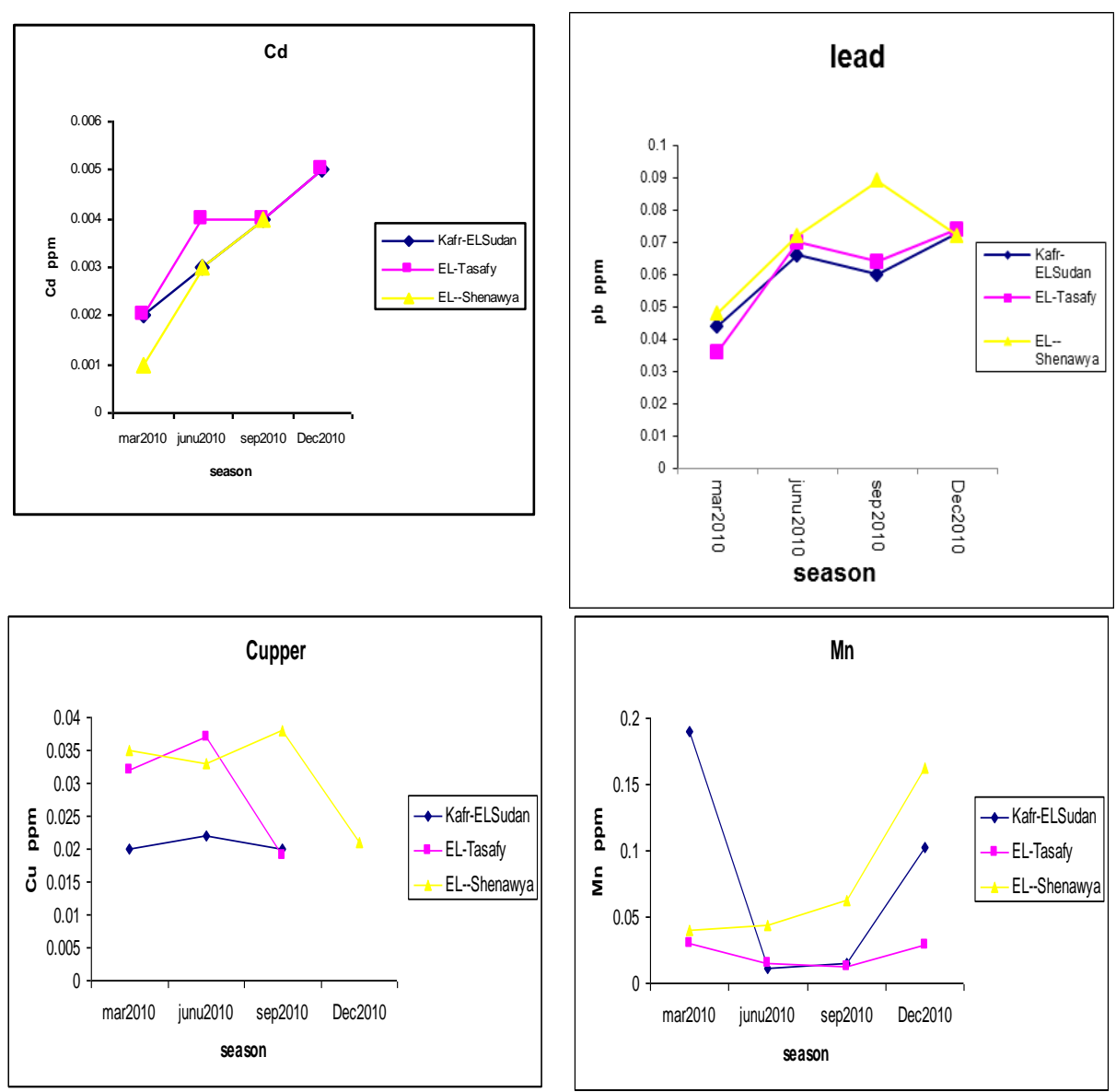

Fig.(3)The concentration of heavy metals in drain No. 10 

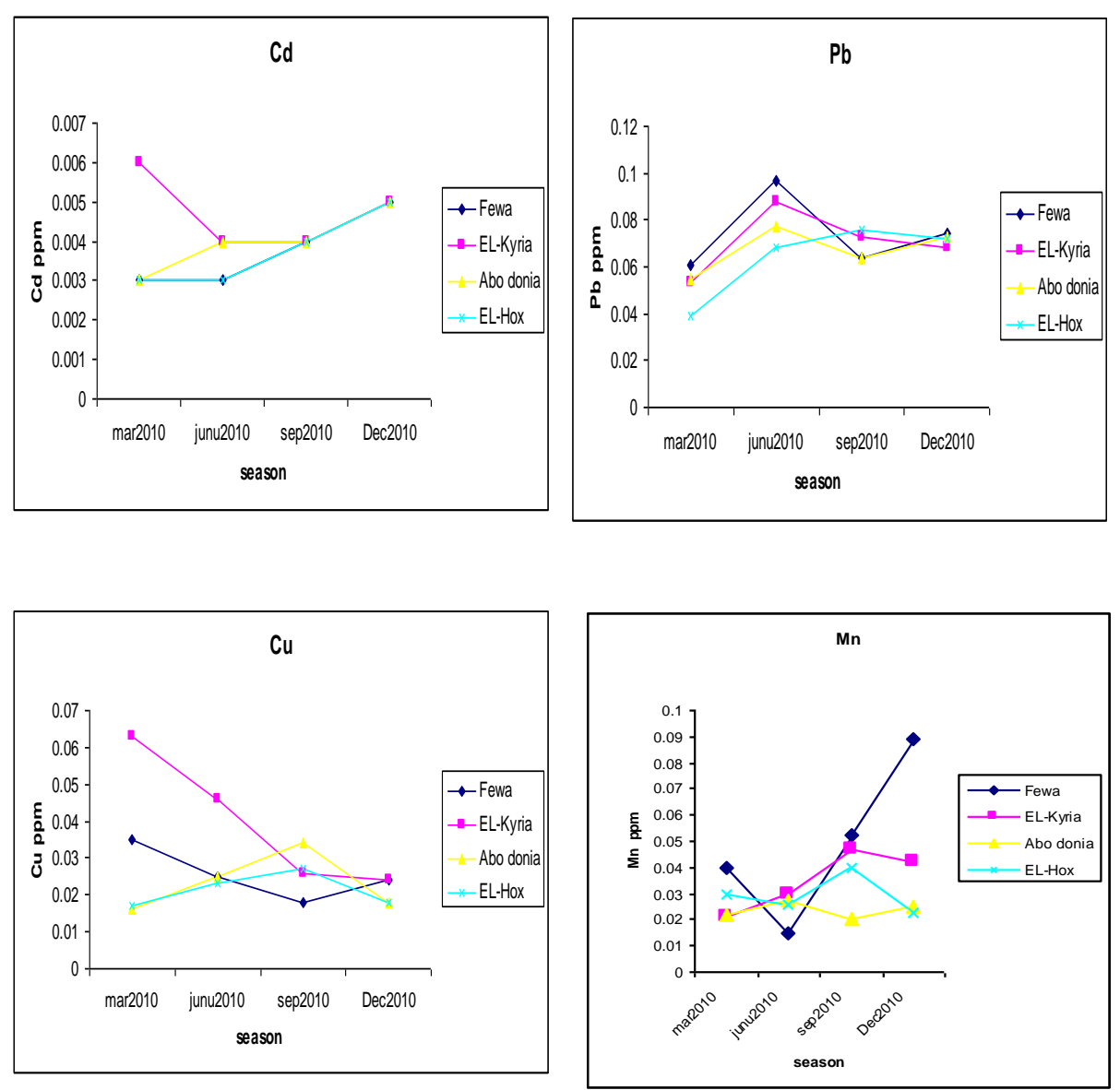

Fig.(4) The concentration of heavy metals in drain No. 11

\section{5 -Nitrate toxicity problems:-}

Nitrate-N values varied from 0.12 to 106 , zero to 6.32 and zero to $1.68 \mathrm{mg} / \mathrm{L}$ in EL-Gharbia main drain, Drain No. 10 and Drain No. 11 ,respectively. As shown in Fig. (5). NO3 concentration in drainage water samples could be classified into three groups. The first group was less than $5 \mathrm{mg} / \mathrm{L}$ and this group is presented in all samples of drain No11, most samples of drain No 10 and some samples of EL-Gharbia main drain. This water could be used in irrigation without any problem . The second group is ranged from $5-30 \mathrm{mg} / \mathrm{L}$ and it could be used in irrigation with special conditions .This group represented in some samples of drain 10 and ELGharbia main drain .The third group was more than $30 \mathrm{mg} / \mathrm{L}$, which represented in some samples of EL-Gharbia main drain during September and December, and it cannot be used in irrigation because of hazard of high nitrate concentration according to the guideline of FAO (1985) . 
Taha, A. A. et al.
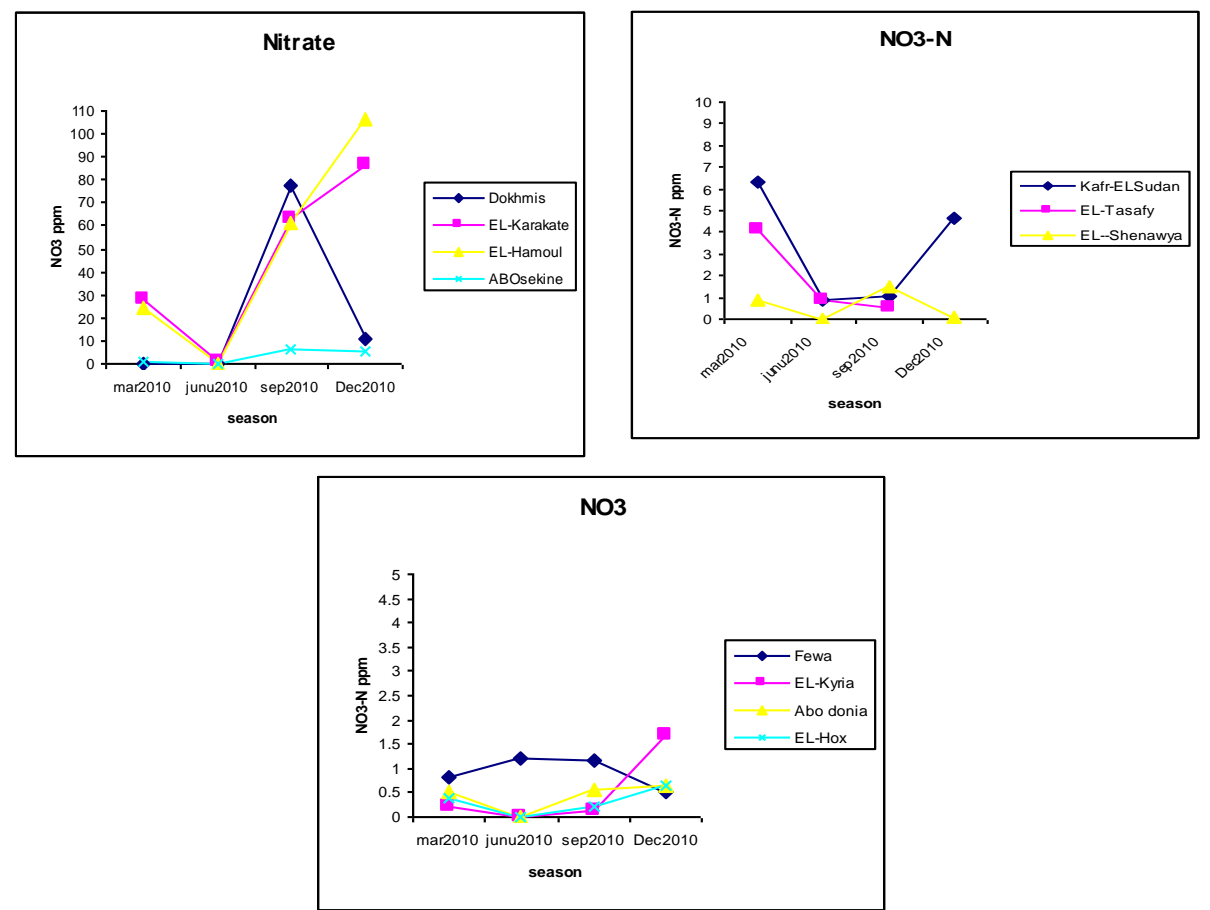

Fig (5) the concentration of Nitrate in tested drains

\section{Impact of irrigation with drainage water on studied crops:}

1-Wheat crop

Data in Table (3)showed that, the concentration of heavy metal ( $\mathrm{pb}$ and $\mathrm{Cd}$ ) and micronutrients $(\mathrm{Mn}, \mathrm{B}$ and $\mathrm{Cu}$ ) in straw of wheat crop was higher than that in the grain at all location. These result are in harmony with those obtain by Wolnick et al. (1985) and Davis and Smith (1980). Manganese and boron concentrations in straw of wheat plant were less than the critical limit $(400-1000 \mathrm{mg} / \mathrm{kg})$ in all locations according to Kabata pendias and pendias(1992). Cadmium concentration in straw of wheat plant was less than the critical limit $(0.1-2.4 \mathrm{mg} / \mathrm{kg})$ in all locations; Also, Cu concentration in wheat straw was higher than the critical limit $(5-20 \mathrm{mg} / \mathrm{kg})$ in all locations. However, $\mathrm{Pb}$ concentration in wheat straw was less than the permissible limit (20 mg/kg) in all locations except Fewa according to Alloway(1995), The trend of $\mathrm{Pb}$ concentration in grain was similar as it was higher than permissible limit in all locations. Also, observed that increasing concentrations of heavy metal in plant at most locations with north direction. This may be due to increasing evaporation at long drains. 
Table (3) Effect of irrigation with drainage water on some heavy metals content and micronutrients in wheat( grain and straw ).

\begin{tabular}{|c|c|c|c|c|c|c|c|}
\hline Drain & Location & $\begin{array}{c}\text { Wheat } \\
\text { crop }\end{array}$ & $\begin{array}{c}\text { B } \\
\text { ppm }\end{array}$ & $\begin{array}{c}\mathrm{Pb} \\
\mathrm{Ppm}\end{array}$ & $\begin{array}{l}\text { Cd } \\
\text { ppm }\end{array}$ & $\begin{array}{c}\text { Mn } \\
\text { Ppm }\end{array}$ & $\begin{array}{l}\mathrm{Cu} \\
\mathrm{ppm}\end{array}$ \\
\hline EL-Gharbia main & & Grain & 1.20 & 1.80 & 0.15 & 8.90 & 5.50 \\
\hline \multirow[t]{7}{*}{ Drain } & Dokhmiss & Straw & 1.37 & 12.30 & 1.50 & 42.50 & 47.50 \\
\hline & \multirow[t]{2}{*}{ EL-Karrakat } & Grain & 1.76 & 1.90 & 0.15 & 12.00 & 5.50 \\
\hline & & Straw & 1.69 & 13.30 & 1.50 & 37.50 & 45.00 \\
\hline & \multirow[t]{2}{*}{ EL-Hamoul } & Grain & 1.23 & 2.05 & 0.15 & 10.00 & 7.75 \\
\hline & & Straw & 1.52 & 13.95 & 1.50 & 40.00 & 47.50 \\
\hline & \multirow[t]{2}{*}{ Abo sekine } & Grain & 1.34 & 1.68 & 0.15 & 10.00 & 7.50 \\
\hline & & Straw & 1.47 & 12.30 & 1.80 & 42.50 & 45.00 \\
\hline \multirow[t]{6}{*}{ Drain NO 10} & \multirow[t]{2}{*}{ Kafer- ELSudan } & Grain & 1.16 & 1.78 & 0.15 & 6.25 & 5.00 \\
\hline & & Straw & 1.38 & 17.75 & 1.50 & 34.30 & 52.50 \\
\hline & \multirow[t]{2}{*}{ EL- Tasfy } & Grain & 1.18 & 1.75 & 0.12 & 7.75 & 6.50 \\
\hline & & Straw & 1.90 & 18.50 & 1.30 & 32.80 & 55.00 \\
\hline & \multirow[t]{2}{*}{ EL-Shenawy } & Grain & 1.36 & 1.85 & 0.12 & 4.25 & 5.00 \\
\hline & & Straw & 1.80 & 18.75 & 1.50 & 25.40 & 50.00 \\
\hline \multirow[t]{8}{*}{ Drain NO 11} & \multirow[t]{2}{*}{ Fewa } & Grain & 1.39 & 1.70 & 0.15 & 5.25 & 5.00 \\
\hline & & Straw & 1.62 & 20.75 & 1.50 & 40.00 & 50.00 \\
\hline & \multirow[t]{2}{*}{ EL-Kayria } & Grain & 1.16 & 1.80 & 0.15 & 5.50 & 5.25 \\
\hline & & Straw & 1.88 & 20.00 & 1.50 & 45.50 & 45.00 \\
\hline & \multirow[t]{2}{*}{ Abo Donia } & Grain & 1.15 & 1.80 & 0.15 & 5.00 & 4.50 \\
\hline & & Straw & 1.71 & 20.00 & 1.50 & 35.00 & 52.50 \\
\hline & \multirow[t]{2}{*}{ EL-Hox } & Grain & 1.31 & 1.70 & 0.15 & 4.75 & 5.75 \\
\hline & & Straw & 1.97 & 15.75 & 1.50 & 37.50 & 50.00 \\
\hline
\end{tabular}

\section{2-Clover crop}

Data in Table (4) showed that $\mathrm{Cd}$, Cu concentrations were less than critical limits $(0.1-2.4$ and $5-20 \mathrm{mg} / \mathrm{kg})$, respectively at all locations in shoot of clover plants and $\mathrm{Pb}$ concentrations were higher than critical limit $(20 \mathrm{mg} / \mathrm{kg})$ at all locations except (EL-Karrakat, EL-Hamoul, EL-Shenawy and Fewa) locations according to Alloway (1995)

On the other hand, $\mathrm{Mn}$ and $\mathrm{B}$ concentrations were less than the critical limit $\quad(400-1000$ and $50-200 \mathrm{mg} / \mathrm{kg})$, respectively at all locations in shoot of clover plants. Also,

Table (4) Effect of irrigation with drainage water on forage clover crop content of some heavy metal and micronutrients

\begin{tabular}{|c|l|l|c|c|c|c|c|}
\hline \multicolumn{1}{|c|}{ Drain } & Location & $\begin{array}{c}\text { Clover } \\
\text { crop }\end{array}$ & $\begin{array}{c}\mathrm{B} \\
\mathrm{ppm}\end{array}$ & $\begin{array}{c}\mathrm{Pb} \\
\mathrm{ppm}\end{array}$ & $\begin{array}{c}\mathrm{Cd} \\
\mathrm{ppm}\end{array}$ & $\begin{array}{c}\mathrm{Mn} \\
\mathrm{ppm}\end{array}$ & $\begin{array}{c}\mathrm{Cu} \\
\mathrm{ppm}\end{array}$ \\
\hline \multirow{3}{*}{$\begin{array}{l}\text { EL-Gharbia } \\
\text { main drain }\end{array}$} & Dokhmiss & Forage & 1.01 & 21.00 & 2.00 & 31.40 & 15.00 \\
\cline { 2 - 8 } & EL-Karrakat & Forage & 1.50 & 18.25 & 2.00 & 40.00 & 13.65 \\
\cline { 2 - 8 } & EL-Hamoul & Forage & 1.09 & 20.00 & 1.50 & 40.00 & 13.00 \\
\cline { 2 - 8 } & Abo sekine & Forage & 1.97 & 21.00 & 1.50 & 37.05 & 13.00 \\
\hline Drain NO10 & Kafer- & Forage & 1.26 & 21.25 & 1.75 & 25.65 & 13.65 \\
& ELsudan & & & & & & \\
\cline { 2 - 8 } & EL- Tasfy & Forage & 1.42 & 21.50 & 1.75 & 28.50 & 12.35 \\
\hline & EL-Shenawy & Forage & 1.80 & 20.00 & 1.50 & 57.00 & 18.85 \\
\hline Drain NO11 & Fewa & Forage & 1.53 & 19.75 & 2.00 & 38.50 & 13.65 \\
\cline { 2 - 8 } & EL-Kayria & Forage & 1.94 & 21.5 & 1.20 & 29.90 & 14.30 \\
\cline { 2 - 8 } & Abo Donia & Forage & 1.20 & 20.25 & 1.50 & 31.35 & 14.30 \\
\cline { 2 - 8 } & EL-Hox & Forage & 2.11 & 20.25 & 1.50 & 52.70 & 13.00 \\
\hline
\end{tabular}


Taha, A. A. et al.

\section{CONCLUSION}

In many parts of the North Delta of Egypt, farmers use drainage water for irrigation, as a result of fresh water shortage in this area. The usage of drainage water in irrigation must be controlled, because it has low quality and contains pollutants, which in turn may cause hazards to soil and grown plants.

To safe reuse of this water in irrigation, it could be recommended that:

- Drainage water resources could be used in the summer season than in winter season.

- Values of EC, SAR, and NO3 increased at the north direction for most location.

- The quality of the studied drainage water is accepted for irrigating most tolerance field crops. However sensitive plants should be excluded from irrigation with these water resources.

- Good management for water, soil and plant is needed to maximize drainage water utilization efficiency and to minimize its the adverse effects. irrigation water must be applied by excess amounts to provide considerable leaching process.

\section{REFERENCES}

AbdEl-Hady,B. A. (2007). Comparing the effect of polluted and river Nile irrigation water on contents of heavy metals of some soils and plants. Research Journal of Agriculture and Biological Sciences. 3:287

Abo -Waly M. E.; A. M. Abou El-Khir; M. A. El-Kammah andM. E. El-Shahawy (1997). Contribution of drainage water to the pollution of Burullus lack by heavy metals. International symposium on sustainable management of salt affected soil in the arid eco-system. Cairo, Egypt,1997.

Alloway, B. J.(1995)Heavy metals in soils. Blackie Academic \&Professional, an imprint of Chapman \&Hall, Estern Cleddens Road, UK.

American Public Health Association (APHA) (1985 .(Standard Methods For the Examination of Water and Waste water $\left.15^{\text {th }}\right)$ ed), Washington, D.C.; U.S.A. P, 525-535

Bingham,F.T.1982. Boron. InA. L. Page. R. H. Miller and D.R. Keeny (eds)method of soil analysis, part 2,Agron.Monogr.9,A.M.Soc. Agron.,Madison, WI.P.431-446ion. Rome.

Chapman, H. D and P.F. Pratt (1961). Methods of Analysis for Soil, Plants and Waters. Univ.of Calif. Division of Agric. Sci. 60-69

EL-Sankary, M.M. (1994). Evaluation of water resources in the North Nile Delta area, Egypt. M.sc these, fac. of Science, Mansoura Uinv.

El-Shahawy, M.I. and M. M. Ragab (2005). Demonstration of sustainable safe reuse of drainage water in agriculture at North Delta. Annual report Agricultural Research Center, Regional Council for agricultural Research and Extension, pp. 20-25. 
Food and Agriculture Organization, (FAO), (1985). Water quality for agriculture. Food and Agriculture Organization of the United Nations, FAO irrigation and Drainage paper No.29, Rome.

Gupta, I.C. (1979). Use of saline water in Agriculture in arid and Semi-Arid Zones of India. Oxford and IBH Publishing Co., New Delhi, 210 P.

Jackson, M. L. (1973). Soil Chemical Analysis. Prentic Hall of India private limited, New

Kabata-Pendias, A. and H. Pendias (1992). Trace Elements in Soils and Plants. CRC Press, Florida -Delhi.

Kalifa, M.R. (1990). Evaluation of suitability of drainage water for irrigation purposes. Its effect on some properties of clay soil in North Delta J.Agric.Res. Tanta univ. 16 (3): 575-582.

Klute, A. (1986). Methods of Soil Analysis (part 1). American society of Agronomy, Inc. Soc. Amer., Inc. Madison, Wisconsin, USA. $3^{\text {rd }}$ edition.

National Academy of science and Engineerin (1972). Water quality criteria United States Environmental Protection Agency, Washington, D.C.Report No.EPA.R 373-033.592P.

Page, A.L.; H. Miller and D.R. Keeney (1982). Methods of Soil Analysis. Part 2, ASA, SSSA, Madison, Wisconsin USA.

Richard, L. A. (1954). The diagnosis and Improvement of saline and Alkali Soils. Usda, Hand Bookn 60.

Rusan,M.M.; S.Hinnawy and L. Rousan (2007).Long term effects of weastewater irrigation of forage crops on soil and plant quality parameters. Desalination.215:143-152

Wolnick,K.A. ; F.L. Fricke; S.G.Capar; G.C.Braude; M.W.Mayer; R.D.Satzgar and E.Bonin (1985) Elements in major raw agriculture crops in united states.3.Cadmium, lead and eleven other elements in carrots, filds corn ,rice, spinach and tomatoes.J Agric. Food Chem. 33:807-811.3

Zean, F.I.; Maani Z. Abou Amou; A. A. El-Leithi and M. M. Ei-Sshami(2002a). Effect of polluted irrigation water on some crops and their contents of heavy metals 1- Wheat. Egypt. J. Soil Sci., 42:139 
Taha, A. A. et al.

صلاحية مياه الصرف لأغراض الرى وتاثير هـا على نبات القمـح والبرسيم المنزرع

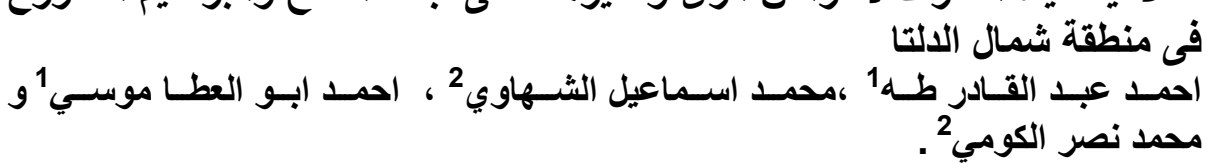

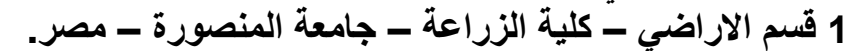
2 معهد بحوث الاراضي والية الزراعياه والبيئة ـ مركز البصورة البحوث الزراعية ـ مصر.

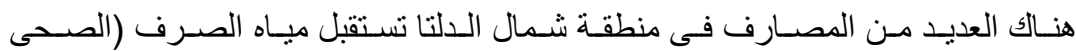

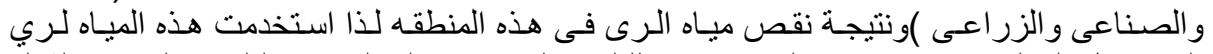

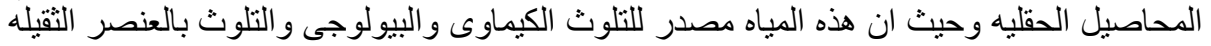

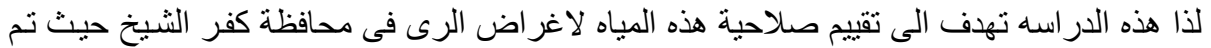

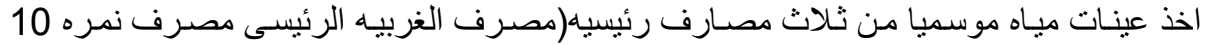

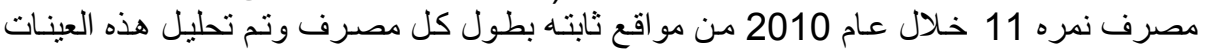

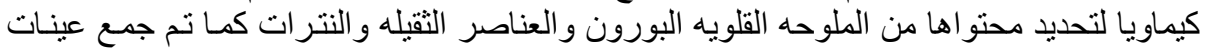

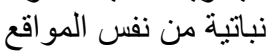
وكانت أهم النتائج المتحصل علئها:

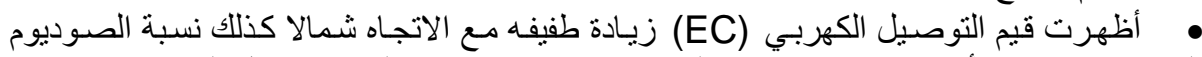

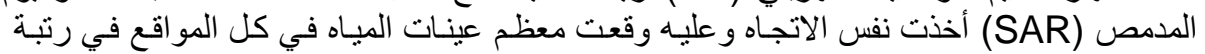

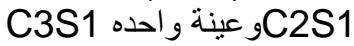

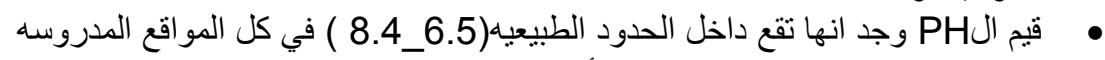

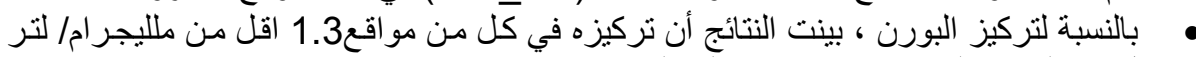

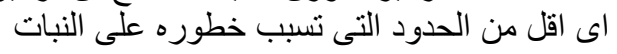

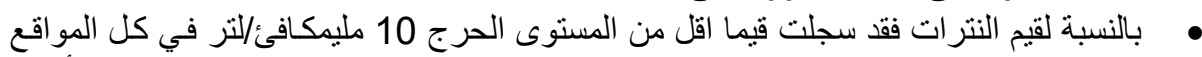

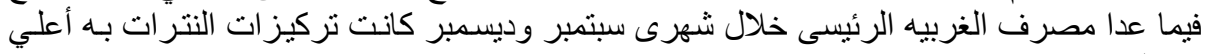

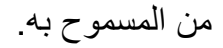

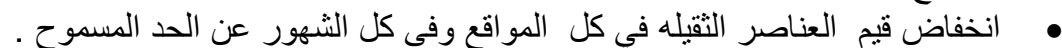

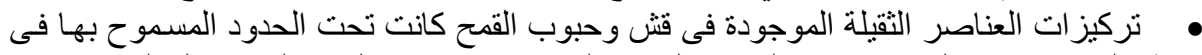

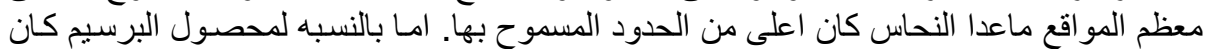

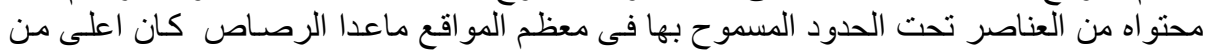

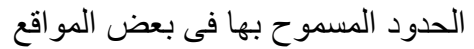

كلية الزراعة - جامعة المنصورة قام بتحكيم البحث مركز البحوث الزراعية

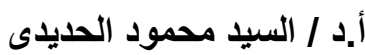
أ.د / أد / الدمد مصطفى محمد لحلح رجب 
J. Soil Sci. and Agric. Eng., Mansoura Univ., Vol. 3 (6), June, 2012 
Taha, A. A. et al. 
J. Soil Sci. and Agric. Eng., Mansoura Univ., Vol. 3 (6): 655 - 668, 2012

Table(3): Evaluation of drainage water for irrigation according to FAO1985

\begin{tabular}{|c|c|c|c|c|c|c|c|c|c|c|c|}
\hline \multicolumn{4}{|c|}{ EL-Gharbia main drain } & \multicolumn{4}{|c|}{ Drain NO. 10} & \multicolumn{4}{|c|}{ Drain NO. 11} \\
\hline Location & $\mathrm{EC} d \mathrm{dS} / \mathrm{m}$ & SAR & $\begin{array}{c}\begin{array}{c}\text { Degree of } \\
\text { restriction } \\
\text { on use by }\end{array} \\
\text { FAO }\end{array}$ & Location & $\mathrm{EC} \mathrm{dS} / \mathrm{m}$ & SAR & $\begin{array}{c}\begin{array}{c}\text { Degree of } \\
\text { restriction } \\
\text { on use by }\end{array} \\
\text { FAO }\end{array}$ & Location & $\mathrm{EC} d \mathrm{dS} / \mathrm{m}$ & SAR & $\begin{array}{c}\begin{array}{c}\text { Degree of } \\
\text { restriction } \\
\text { on use by }\end{array} \\
\text { FAO }\end{array}$ \\
\hline & & & (1985) & & & & $(1985)$ & & & & (1985) \\
\hline \multicolumn{12}{|c|}{ March 2010} \\
\hline Dokhmiss & 1.00 & 4.9 & $\begin{array}{c}\text { Slight to } \\
\text { moderate }\end{array}$ & $\begin{array}{l}\text { Kafer- } \\
\text { ELsudan }\end{array}$ & 1.15 & 5.3 & $\begin{array}{c}\text { Slight to } \\
\text { moderate }\end{array}$ & Fewa & 0.99 & 4.9 & $\begin{array}{c}\text { Slight to } \\
\text { moderate }\end{array}$ \\
\hline EL-Karrakat & 1.10 & 5.2 & $\begin{array}{l}\text { Slight to } \\
\text { moderate }\end{array}$ & EL-Tsafy & 1.55 & 6.1 & $\begin{array}{c}\text { Slight to } \\
\text { moderate }\end{array}$ & EL-Kayria & 1.10 & 5.2 & $\begin{array}{c}\text { Slight to } \\
\text { moderate }\end{array}$ \\
\hline EL-Hamoul & 1.20 & 5.4 & $\begin{array}{c}\text { Slight to } \\
\text { moderate }\end{array}$ & EL-Shenawy & 2.25 & 7.4 & None & Abo Donia & 1.30 & 5.6 & None \\
\hline Abo sekine & 0.57 & 3.4 & $\begin{array}{c}\text { Slight to } \\
\text { moderate }\end{array}$ & -- & -- & -- & -- & EL-Hox & 1.50 & 6.0 & $\begin{array}{c}\text { Slight to } \\
\text { moderate }\end{array}$ \\
\hline \multicolumn{12}{|c|}{ Junue 2010} \\
\hline EL-Karrakat & 1.15 & 5.3 & $\begin{array}{l}\text { Slight to } \\
\text { moderate }\end{array}$ & EL-Tsafy & 1.20 & 5.4 & $\begin{array}{l}\text { Slight to } \\
\text { mderate }\end{array}$ & EL-Kayria & 1.00 & 4.9 & $\begin{array}{c}\text { Slight to } \\
\text { moderate }\end{array}$ \\
\hline EL-Hamoul & 1.35 & 5.7 & None & EL-Shenawy & 1.55 & 6.1 & $\begin{array}{l}\text { Slight to } \\
\text { moderate }\end{array}$ & Abo Donia & 1.25 & 5.5 & None \\
\hline Dokhmiss & 1.10 & 5.2 & $\begin{array}{c}\text { Slight to } \\
\text { moderate }\end{array}$ & $\begin{array}{l}\text { Kafer- } \\
\text { ELsudan }\end{array}$ & 0.98 & 4.9 & $\begin{array}{c}\text { Slight to } \\
\text { moderate }\end{array}$ & Fewa & 0,72 & 4.2 & $\begin{array}{c}\text { Slight to } \\
\text { moderate }\end{array}$ \\
\hline Abo sekine & 0.80 & 4.4 & $\begin{array}{c}\text { Slight to } \\
\text { moderate }\end{array}$ & -- & -- & -- & -- & EL-Hox & 1.30 & 5.6 & None \\
\hline \multicolumn{12}{|c|}{ Septamber2010 } \\
\hline Dokhmiss & 1.25 & 5.5 & None & $\begin{array}{l}\text { Kafer- } \\
\text { ELsudan }\end{array}$ & 1.2 & 5.4 & $\begin{array}{c}\text { Slight to } \\
\text { moderate }\end{array}$ & Fewa & 0.83 & 4.5 & $\begin{array}{c}\text { Slight to } \\
\text { moderate }\end{array}$ \\
\hline EL-Karrakat & 1.30 & 5.6 & None & EL-Tsafy & 1.55 & 6.1 & $\begin{array}{c}\text { Slight to } \\
\text { moderate }\end{array}$ & EL-Kayria & 0.95 & 4.8 & $\begin{array}{c}\text { Slight to } \\
\text { moderate }\end{array}$ \\
\hline EL-Hamoul & 1.40 & 5.8 & None & EL-Shenawy & 1.85 & 5.3 & None & Abo Donia & 1.10 & 5.2 & $\begin{array}{c}\text { Slight to } \\
\text { moderate }\end{array}$ \\
\hline Abo sekine & 0.82 & 4.5 & $\begin{array}{c}\text { Slight to } \\
\text { moderate }\end{array}$ & -- & -- & -- & -- & EL-Hox & 1.30 & 5.6 & None \\
\hline \multicolumn{12}{|c|}{ December 2010} \\
\hline Dokhmiss & 1.00 & 4.9 & $\begin{array}{c}\text { Slight to } \\
\text { moderate }\end{array}$ & $\begin{array}{l}\text { Kafer- } \\
\text { ELsudan }\end{array}$ & 1.15 & 5.3 & $\begin{array}{c}\text { Slight to } \\
\text { moderate }\end{array}$ & Fewa & 0.92 & 4.7 & $\begin{array}{c}\text { Slight to } \\
\text { moderate }\end{array}$ \\
\hline EL-Karrakat & 1.15 & 5.3 & $\begin{array}{c}\text { Slight to } \\
\text { moderate }\end{array}$ & EL-Tsafy & 1.55 & 6.1 & $\begin{array}{c}\text { Slight to } \\
\text { moderate }\end{array}$ & EL-Kayria & 1.20 & 5.5 & $\begin{array}{c}\text { Slight to } \\
\text { moderate }\end{array}$ \\
\hline EL-Hamoul & 1.35 & 5.7 & None & EL-Shenawy & 1.90 & 6.8 & $\begin{array}{c}\text { Slight to } \\
\text { moderate }\end{array}$ & Abo Donia & 1.20 & 5.4 & $\begin{array}{c}\text { Slight to } \\
\text { moderate }\end{array}$ \\
\hline Abo sekine & 0.91 & 4.7 & $\begin{array}{c}\text { Slight to } \\
\text { moderate }\end{array}$ & -- & -- & -- & -- & EL-Hox & 1.80 & 6.6 & $\begin{array}{c}\text { Slight to } \\
\text { moderate }\end{array}$ \\
\hline
\end{tabular}

